Meta

Journal des traducteurs

Translators' Journal

\title{
Hysteron-proteron: A Polyfunctional Rhetorical Device - with Reference to Arabic-English Translation
}

\section{Salah Salim Ali}

Volume 52, numéro 3, septembre 2007

URI : https://id.erudit.org/iderudit/016727ar

DOI : https://doi.org/10.7202/016727ar

Aller au sommaire du numéro

\section{Éditeur(s)}

Les Presses de l'Université de Montréal

ISSN

0026-0452 (imprimé)

1492-1421 (numérique)

Découvrir la revue

Citer cet article

Ali, S. (2007). Hysteron-proteron: A Polyfunctional Rhetorical Device - with Reference to Arabic-English Translation. Meta, 52(3), 401-411.

https://doi.org/10.7202/016727ar
Résumé de l'article

L'hystéron-protéron est une façon rhétorique dans les travaux littéraires et presque dans toutes les sociétés avec écriture.

D'un point de vue linguistique, il s'agit d'une forme d'inversion, de topicalisation ou de permutation qui se produit au niveau de la phrase et inclut une déviation dans la progression syntagmatique des phrases, de même qu'un changement sémantique englobant le champ, la mise en évidence et en relief (Jakobson 1972 : 78-80), en plus de jouer un rôle dans certains procédés grammaticaux comme l'interrogation et la passivation (Jack et al. 1989).

L’hystéron-protéron a une grande importance esthétique et poétique et constitue l'une des façons rhétoriques qui peut modifier structuralement la structure et le sens d'un texte en fonction des intentions de l'auteur. En d'autres termes, il s'agit d'un choix stylistique qui exerce une influence pragmatique sur le lecteur.

Cependant, son fort lien avec la syntaxe, la sémantique et la stylistique engendre des difficultés de traduction qui sont plus saillantes lorsque les langues ont des positions diamétralement opposése, comme l'arabe et l'anglais. Après avoir exposé l'hystéron-protéron et illustré sa polyfonction, sa présence dans la prose, la poésie et la littérature arabe sacrée (par exemple le Coran), l'article donne aussi l'influence du style occidental sur l'expression littéraire de textes narratifs arabes. 


\title{
Hysteron-proteron: A Polyfunctional Rhetorical Device - with Reference to Arabic-English Translation
}

\author{
SALAH SALIM ALI \\ Cultural Department, Kristiansand Kommune, Norway \\ semiramis2005@yahoo.com
}

\section{RÉSUMÉ}

L'hystéron-protéron est une façon rhétorique dans les travaux littéraires et presque dans toutes les sociétés avec écriture.

D'un point de vue linguistique, il s'agit d'une forme d'inversion, de topicalisation ou de permutation qui se produit au niveau de la phrase et inclut une déviation dans la progression syntagmatique des phrases, de même qu'un changement sémantique englobant le champ, la mise en évidence et en relief (Jakobson 1972: 78-80), en plus de jouer un rôle dans certains procédés grammaticaux comme l'interrogation et la passivation (Jack et al. 1989).

L'hystéron-protéron a une grande importance esthétique et poétique et constitue l'une des façons rhétoriques qui peut modifier structuralement la structure et le sens d'un texte en fonction des intentions de l'auteur. En d'autres termes, il s'agit d'un choix stylistique qui exerce une influence pragmatique sur le lecteur.

Cependant, son fort lien avec la syntaxe, la sémantique et la stylistique engendre des difficultés de traduction qui sont plus saillantes lorsque les langues ont des positions diamétralement opposése, comme l'arabe et l'anglais.

Après avoir exposé l'hystéron-protéron et illustré sa polyfonction, sa présence dans la prose, la poésie et la littérature arabe sacrée (par exemple le Coran), l'article donne aussi l'influence du style occidental sur l'expression littéraire de textes narratifs arabes.

\section{ABSTRACT}

Hysteron-proteron is one of the rhetorical devices present in all literary works and in almost all literate cultures.

Linguistically, it is considered a kind of inversion, topicalization or permutation that occurs on the sentence level and involves deviation in the syntagmatic progression of sentences as well as a semantic shift encompassing scope, focus and emphasis (Jakobson 1972: 78-80) besides fulfilling certain grammatical processes such as interrogation and passivization (Jack et al. 1989).

Literarily, hysteron-proteron has a great aesthetic and poetic relevance as it is one of the rhetorical devices that can structurally modify both the texture and sense of the text according to the writer's taste and intention. In other words, it offers one of the stylistic options that will consequently exercise certain pragmatic impact on the reader.

It goes without saying, however, that by virtue of its strong affinity to syntax, semantics and style, hysteron-proteron usually involves translation problems which acquire more salience when the languages hold two diametrically opposing standpoints as is the case with Arabic and English.

After expounding hysteron-proteron and, diagrammatically, illustrating its polyfunctionality, an account is provided on its occurrence in prose, poetry and in Arabic sacred literature i.e., the Qur'an, tackling its deeper sedimented layers in the Arab mind. The paper also legislates for the unmistakable impact of Western style of literary expression on some Arabic narrative texts. This just projects one more benefit of translation when 
used as a probing device in detecting literary borrowing through awkward or blind literal rendering of purposefully-disrupted word-order in English into Arabic or vice versa.

\section{MOTS-CLÉS/KEYWORDS}

hysteron-proteron, prominence, polyfunctionality, markedness, adequacy

In ordinary discourse, the deliberate placement of certain sentence elements at the beginning of the sentence gives prominence or an emphatic effect to these elements. The sentence: "I like this teacher because he is intelligent" reads smoothly because the continuity of its component parts which are set in a syntagmatically normal wordorder is not broken. However, the replacement of the subordinator by a semicolon breaks this continuity and makes the sentence look more emphatic i.e., "I like this teacher; he is intelligent." Hysteron-proteron, on the other hand, will bring the clause of reason at the beginning of the sentence and highlight the intelligence of the teacher. Thus, "Because he is intelligent, I like this teacher." This departure from the norm through placing the clause of reason at the beginning of the sentence gives the sentence a stylistic markedness and adds an effect of excitability to the whole utterance.

In literary discourse the effect of hysteron-proteron becomes double-fold. This is because a literary text as a whole is totally marked for poetic and stylistic relevance, and because this text normally teems with other rhetorical devices that are equally marked for stylistic, emotive, and poetic relevance. In hysteron-proteron, we discern a sort of interaction or reticulation between grammar and rhetorics where the manipulation of various sentence elements is, in most cases, motivated by the intention, on the part of the writer, to affect certain cognitive or emotional impact on the reader. This, however, is done by the conscious choice of hysteron-proteron as a rhetorical device. Thus, the rhetorical device here affects the grammatical necessity by way of grammatical manipulation. But, although hysteron-proteron is so pervasive and so intrinsic in all languages, it seems it is more salient in languages whose wordorder is relatively rigid, as English, than it is in languages whose word-order is flexible, as Arabic $^{3}$ (Pickering and Hoeper 1982: 822).

This, of course, gives rise to translation problems since what is stylistically marked in English will either be blurred or obliterated in the Arabic version, and alternately, what is stylistically unmarked in the Arabic original may acquire a stylistic markedness in the English counterpart. ${ }^{4}$ (Hawkins 1983: 12-26). Also, hysteron-proteron, in addition to its stylistic function does achieve several semantic functions such as: emphasis, notional sequentiality, dramatic effect, and, in poetry, metrical harmony. Yet, the scope, recurrence, and significance of these functions differ from text to text and from English to Arabic. In sacred literature, for instance, these functions assume more significance and even pragmatic relevance than they do in drama, narrative, or poetic texts. And while certain typographical contrivances such as italicization, capitalization, punctuation as well as variation in sentence length serve the function of emphasis in English, Arabic, which lacks these typographical manipulations, resorts to either hysteron-proteron or to certain emphatic particles such as "li" (the inserted li) and "lamu 't-tawkid" (the inchoative la) or the use of the energetic. But, it is rather through hysteron-proteron that Arabic injects a note of real significance into the tort. Obviously, this significance is mainly due to the capacity of hysteron-proteron to yoke both grammar and rhetorics in the same time. Its complex nature gains in highlight when we set it off against some non-grammatical indicators such as parallelism and 
repetition. For besides its projection of propositional alternatives, hysteron-proteron disrupts the syntagmatic procession of the sentence by inoculating it with an additional semantic charge or illocutionary force that gives the whole text a new turn of meaning. This becomes clear from the transformations of the following sentence from Spenser's Fairy Queen (Liii, 17)

The holy Saints of their rich vestments

He did disrobe. (OASV)

Which can be reordered as:

Of their rich vestments the holy Saints

He did disrobe. (AOSV)

And as:

He did disrobe the holy Saints of their vestments. (SVOA)

We notice that our reading of the first sentence is somewhat slower than our reading of the last sentence. But our perception of the third sentence, however, does widely differ from our perception of the first as far as style and poetics are concerned. The first sentence puts the phrase "the holy Saints" at the beginning for emphasis and places the verb at the end for climaxing or dramatic effect. Both these effects, that is, the emphatic and the dramatic, disappear in the third sentence. Thus, the difficulties in perceiving a sentence of the tortuous type is mainly due to the additional information load to be processed in comparison to the normal type sentence which lacks this additional information. This is why we grasp cumming's $\mathrm{s}^{5}$ round-about semantics more readily than Milton's diabolic syntax. It follows that hysteron-proteron does greatly affect various elements in the architecture of the 1iterary text, adding, besides surface features, functional, and aesthetic dimensions so as to provide a meetingground for stylistics, rhetorics, and syntax. Hysteron-proteron resembles architecture in that it yokes both form and function of the text for, in addition to creating significant changes in the surface features i.e., syntax of the literary text, it affects, by way of relevance to style and poetics, an important functional dimension. It combines style, rhetorics, and syntax in one focus. It also shares painting in that it creates a foregrounding effect. This is achieved by giving certain elements in the sentence, and consequently, the whole text, a noticeable prominence that calls our attention to this prominence more than to other elements in the text.

Adam accuses God in Book X of Paradise Lost, saying:

Inexplicable thy justice seems.

In placing the adjective inexplicable at the very beginning, Milton puts in Adam's mouth a tone of indignation, dissatisfaction and even irony, for the act of God cannot be accommodated to the human sense of poetic justice (Carey and Fowler 1968: 754755). Normal ordering of the same sentence will render it a mere statement stripped of enquiry, drama, and emphasis. This confirms the stylistic aspect of hysteronproteron and points out the possibility of using foregrounding as an artistic device in literary texts. So it becomes evident that hysteron-proteron shares with other stylistic devices their potentiality as an indicator to the personality or, at least, to one aspect of the ideological biases or convictions of the writer. 
The following quotation from Hamlet (Wells et al. 1971) clearly shows how hysteron-proteron is deliberately made to reflect the dramatist's view of a sane world turned insane, at the same time foreshadowing Ophelia's oncoming madness:

Ophelia: O what a noble mind is here o'erthrown!

The courtier's, soldier's, scholar's, eye, tongue, sword.

Here, Shakespeare uses what Arab rhetoricians term al-laf wan-nashr - a figure of speech where a series of genitive nouns does synechdochically correspond with the order of the things possessed. This figure, normally occurs in a way that makes the correspondences agree logically and semantically between the genitive nouns and the things those nouns possess as in the following line by Al-Mutanabbi (Mustapha 1986: 228).

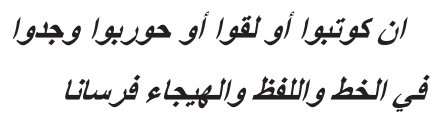

If they were to be addressed by pen, by tongue, or by sword; they will be found

In script, in utterance, and in war; true cavaliers.

However, Shakespeare disrupts the logical order between these genitive nouns, and the nouns related to them by reverting their order. So, instead of tongue, sword, eye, we have eye, tongue, sword; and instead of providing each genitive noun that is courtier's, soldier's, scholar's with its suitable synecdoche so as to become the courtier's tongue, the soldier's sword, and the scholar's eye, Shakespeare separated each genitive noun from its respective possessed synecdoche. Thus, in this example, we have a triple disturbance semantic, syntactic, and contextual. Nevertheless, any logical rearrangement of the statement will betray its aesthetic value and thematic significance. The hysteron-proteron here serves rhetorical, thematic, and aesthetic purpose, and Shakespeare, by such linguistic delirium, highlights a real dementia Ophelia thought Hamlet to suffer from and prepares, at the same time, the audience for an impending madness to befall Ophelia herself while masking a political remark by hinting at a possible disorder in the Elizabethan society at large. This, also, tells us something about Lear's request of Gloucester to read with his ear. Shakespeare seems to anticipate modern psychiatry in diagnosing the linguistic disturbances accompanying the onset of dementia and mental illness.

It is obvious from this example that Shakespeare believed that there was a sort of isomorphy between the structure of language and the external objects and events language describes, so disorder in the mind is likely to be reflected in a similar disorder in language. This he achieves through disruption of the syntagmatic relations of words in an utterance, for it needs a madman to place the cart before the horse. To read with ears is a paradigmatic deviation from the norm and was made when Lear went mad. The playwright, in this instance, turns into a psychiatrist who transforms the stage into a clinic and the audience into participators and critics. It is interesting to study this feature at length in Shakespeare and other writers, but I would rather take leave of this topic to tackle hysteron-proteron from a generic and functional vantage point.

Hysteron-proteron as a rhetorical device consciously used ${ }^{6}$ (Wertsch 1982: 140141) to perform stylistic, artistic, and thematic functions in the text is restricted to 
literary use of language. There is no sense, therefore, in using it in the description of universal truths, historical events (though it is occasionally used in history books for an emphatic purpose) and in technical and science subjects. It is worth mentioning, however, that even in the literary texts, the recurrence and functions of hysteronproteron vary. This becomes evident as we compare religious to poetic texts, or the latter to narrative or ordinary discourse.

Hysteron-proteron occurs in religious or sibylline texts mainly for moral, thematic, and, therefore, ideological function; whereas it occurs in poetic texts mostly for artistic and aesthetic function. Alternately, its choice in narrative texts is predominantly made to fulfill a stylistic function. This division, of course, is not an absolute one for all sorts of literary texts be they religious, poetic, or narrative tend to harbour hysteron-proteron for one or more than one function (Shklovsky 1989: 65). In other words, the use of hysteron-proteron in narrative texts is not exclusive of thematic or artistic functions, nor is its use in religious texts to the exclusion of stylistic or artistic functions. The following diagram makes the interrelationships among genres and functions more explicit:

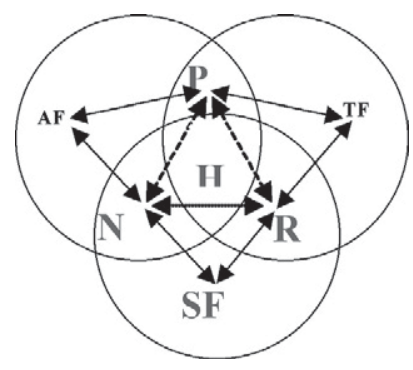

Generic relationships between types of texts and hysteron-proteron function HP = hysteron-proteron, $\mathrm{PT}=$ poetic text, $\mathrm{NT}=$ narrative text, $\mathrm{RT}=$ religious text, $\mathrm{AF}=$ artistic function, $\mathrm{SF}=$ stylistic function, $\mathrm{TF}=$ thematic function.

Of course, this generic and functional distinction has a relevance of a paramount importance to Arabic-English translation. For while hysteron-proteron in modern Arabic narrative reflects stylistic borrowings from the West, it does not reflect any stylistic borrowing in classical poetry or in sacred literature where the traditional stylistic features persist. This, in turn, makes the translation of hysteron-proteron in Arabic narrative texts a sort of backtrack.

Noticeable in this connection too is the fact that although the range of Arabic literary works translated into English is very limited, representative works on prose, poetry, and sacred literature exist in English to allow comparisons to be made between the original Arabic and their translated counterparts in English. In the following section, examples of English translations of Arabic prose, poetry, and sacred literature where hysteron-proteron occurs are provided and discussed in order to see whether the English version has accounted for the stylistic, artistic, and thematic aspects the original Arabic harbours or whether, it has affected some alterations.

Evidently, borrowing from the West especially from English and French literature and usage has greatly influenced modern Arabic literary style. This impact is most salient in narrative and drama which (with the exception of several classics such as 
The Arabian Nights and Kalila Wa Demna - themselves largely non-Arabic in origin) constitute two principal Western literary genres introduced into Arabic during the nineteenth century. Historically, Arab intelligentsia have, since Napoleon's invasion of Egypt and the subsequent Westernization efforts in the Arab Ottoman provinces, begun to adopt Western ways of thinking and feeling. These ways, in addition to stylistic modes of expression, found their way uninterrupted into Arabic through translation and other ways of acculturation with the West. Some of these changes are all-too-evident through interference of English threads of thinking into Arabic text texture (Stetkevych 1970: 95-113).

However, these stylistic borrowings as reflected in Arabic narrative show a growing tendency towards structure variation, the use of short sentences, over-exaggerated use of subordination and adverbials, as well as stress on meaning by way of foregrounding, repetition, hysteron-proteron, and even punctuation used instead of the conjunct waw (and) in the catalogue sentence.

Unlike the translation of classical literature, the translation of modern Arabic literary works into English is not hampered by stylistic difficulties since the same English borrowings will take away their Arabic mask and put on, once again, their English face. Thus, في الدقام الاول will become, when taking off its mask, (in the first place), الطعم ابتلع will become (he swallowed the bait). However, a stylistically marked sentence for hysteron-proteron in Arabic may lose its effect when it is unmarkedly rendered into English. Thus, the statement: الظلم والظلام عبثا انتظر زوال which is stylistically marked in Arabic, (though it begins with an originally English stylistic feature previously introduced into Arabic) will lose its markedness when translated as (I wait in vain for the disappearance of oppression and darkness). Nevertheless, a similar stylistic effect is reproduced in English translations when hysteron-proteron used for foregrounding in the original Arabic text is rendered without displacement into English:

It the afternoon, when the sun is low, the doum tree casts its shadow from this high mound right across the river... At dawn, when the sun rises, the shadow of the tree stretches across the cultivated land and houses right up to the cemetery (Johnson-Davies 1981: 129).

The effect becomes effaced if the adverbials - in bold - were placed after the relative clause. The emphasis, in this case, will be laid on the shadow of the doum tree, not on the temporal sequence.

Introducing sentences with adverbials or prepositions is an English way of expression borrowed in literary Arabic to induce a stylistic effect. As the following translations show, the same stylistic effect is maintained intact in the English version. The result is almost a back-translation of original English.

1. Tomorrow you will depart from our village, of this I am sure (Johnson-Davies 1981: 84).

2. Quietly, I said that inanimate things don't feel, don't talk, don't move (Johnson-Davies 1981: 130).

3. Suddenly, a female cry, an anguished call for help, rang out (Johnson-Davies 1981: 130).

4. Between ${ }^{7}$ myself and this sheikh, whose nature was compounded of simplicity, stupidity, and cunning, there existed an age-long enmity (Johnson-Davies 1981: 25).

The Arabic stylistic prototypes have the above underlined adverbials and the last preposition normally placed in a final or a mid position. Example 1 in a final position 
while examples 2, 3 and 4 in a mid position. When reordered, the stylistic prominence will disappear and the dramatic effect will accordingly diminish. Thus:

1. You will depart from our village tomorrow. . . etc.

2. I said quietly that animate things don't feel. . . .etc.

3. A female cry, an anguish call for help, suddenly rang out.

4. An age-long enmity between myself and this sheikh whose nature was compounded of simplicity, stupidity, and cunning existed.

Nagib Mahfouz uses the same stratagem to create similar effect:

At every street corner, I called out Zacbalawi! In the vague hope that I would be rewarded with an answering shout (Johnson-Davies 1981: 144). It is worth mentioning that these chances in modern Arabic literary style are not a characteristic of a single writer, but they are rather pervasive in all literary genres and with almost all writers. Nevertheless, stylistic distinctive features may crystallize in a particular literary genre signalizing a particular author. So we can identify the writer by way of his stylistic distinctive features in a similar manner to that by which we identify artists in fine and plastic arts. Thus, we may speak of Mahfouz's style in a like manner ${ }^{8}$ as when we identify Seurat with Pointillism, Moore with Recumbent figure sculpture, (Bronowski, 1980: 115-116), and Palladio with Palladian bridges all over Western Europe Taking it a little further, we may identify Hemingway's style (Scholes 1985: 25-73) with thematic density expressed mostly by implication and ellipted structure, Faulkner's ${ }^{9}$ with a heterodiegetic plot accompanied by long strings of logo-centric adjectives, and Robbe-Grillet's style ${ }^{10}$ with suspense enhancement achieved by creating a paradoxical situation, tension, and uncertainty whose end completely betrays the expectations of the reader.

These stylistic innovations in Modern Arabic Literary language have, of course, included hysteron-proteron. But as we have already stressed, the employment of this device here is being mostly made through borrowing of English stylistic habits into Arabic as well as through the writer's intention to project certain elements in a sentence which may otherwise be passed by unnoticed. The following example elucidates this aspect:

Snakelike, it made its way through the dry desert

Slowly traversing the brown arid wastes...etc. (Johnson-Davies 1981: 129).

This style is reminiscent of Milton's for only after ten lines we perceive that the writer is describing an old railway coach. Obviously, this introduction of the story with snakelike adds both thrill and drama to the narrative.

In poetry, hysteron-proteron is made for poetic metrical necessity and as an artistic treatment of words within the line fulfilling both rhetorical and aesthetic function. The following, almost singular, line from Al-Mutanabbi serves an example:

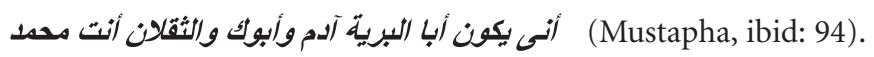

How might it have come to pass that Adam is the father of mankind?

And your father, and mankind and demons you, Muhammad!

In the second hemistich the poet placed "Muhammad' (the addressee's father) at the end and placed the personal pronoun "'anta" (you) after الثقان (both mankind 
and demons). Thus, hysteron-proteron is being twice made in the second hemistich which, if read without inversion, becomes:

$$
\text { ومحمد أبوك وأنت الثقلان }
$$

That is: (Your father is Muhammad true and you are both mankind \& demons). Metrical necessity in this line forced the transposition of the predicate to a final position. But since both his patron prince and his father Muhammad were the object of panegyric, the poet, all of a sudden rethought istadraka the theme and interposed the interpolated statement والثقلان أنت (and both mankind and demons you) between وأبوك (and your father), and the predicate محد (Muhammad).

Another example is provided by Labid:

$$
\text { أو لم تكن تلدي نوار بأنـي وصال عقد حبائل جذ/مها (Az-Zawzani 1971: 109). }
$$

Here, the noun of كان is retracted while its predicate is transposed for both metrical necessity and artistic effect. In fact, the metrical harmony brings about the aesthetic effect and hence the artistic function of hysteron-proteron in poetry.

In translation, artistic adequacy is mostly scarified for the sake of semantic adequacy. Thus, Bateson's translation of Labid's line did not keep to the original:

Truly did Nawar not know that I am

A firm-fastener of the knot of cords, (and) their severer (Bateson 1970: 165).

If artistic function accounts for the use of hysteron-proteron in poetic texts, thematic function accounts for its use in sacred literature. Obviously, certain factors combine to single out Qur'an as a special text. Central among these factors are its rhetorical brevity, compact structure, pervasive use of metaphor and a unique indulgence in abstract ethical terminologies. Moreover, Qur'an shares with pre-Islamic literature the formal aspect of سجع (rhymed prose) and the metaphoric representation of pre-Islamic poetry (Nicholson 1979: 74). But unlike both types of pre-Islamic literary production, it harbours many subtle concepts expressed in a correspondingly subtle language. And hysteron-proteron is one way of expressing these concepts. However, hysteron-proteron in the Qur'an is made in a rather singular manner. The verse is told twice. In the second version, a specific word or phrase in the verse is being transposed so as to project another quite different meaning from that of the first version. On the surface, the two verses look the same while they are not so in their deep structure.

It is worth-bearing in mind that this aspect in the Qur'an is behind the widespread opinion that Qur'an is crowded with repetitions. The following is an extreme testimony:

The book is strikingly lacking in overall structure, frequently obscure and inconsequential in both language and content, perfunctory in its linking of disparate materials, and given to repetition of whole passages in variant versions (Patricia and Cook 1977: 18).

Nevertheless, some repetitions in the Qur'an are made with the aim of achieving a specific effect. Likewise are several cases where hysteron-proteron occurs.

Foregrounding, for instance, is the motive behind opening the following verses with the object in place of the subject: 
1. على الله توكلت

Acraf, verse 89

In Allah do we put our trust (Pickthall 1981: 164)

2. أنيب عليه توكلت واليه

Hud, verse 88

In Him I trust and unto Him I return (Pickthall 1981: 227).

This has set a kind of prototypical effect in the Muslim mind. For most mystical and religious writings in later generations followed in the footsteps of the Qur'an since it was a matter of carelessness if not purposeful heresy not to start any statement with the name of God.

On the other hand, we notice that notional relations motivate the hysteronproteron of the prepositional phrase in the following verses:

1. وترى الفلك مواخر فيه

An-Nahl, verse 14

And thou seest the ships ploughing it (Pickthall 1981: 251).

2. وترى الفلثك فيه مو/خر

Fatir, verse 12

And thou seest the ships cleaving them (Pickthall 1981: 427).

We discern that the antecedence of الف (the ships) to the word denotative of a state فواخر (sailing), and its prepositional phrase فيه (in it) that is (in the sea) in the first verse is notionally manipulated so as to fit a context where the topic is a catalogue sentence enumerating several means of transport such as cattle, horses, mules, and asses, whereas the prepositional phrase (in the sea) precedes the word denotative of a state in the second verse because the context here entails a description of the sea and the myriad kinds of creatures, jewels, and activities the sea does embrace. However, Pickthall's translation obliterates this distinction. Little change may give these verses some suggestive overtones:

- And thou seest the ships (among other things) cleaving their way in it.

- And thou seest the ships in it (being all-embracing-cleaving their way.

Likewise, hysteron-proteron serves elucidating notional relations in the following verse where the provisions of the fathers are given precedence to the provisions of the sons. Here, the Qur'an addresses the poor to the exclusion of the rich:

- ولا تقتلوا أولادكم من إملاق . نحن نرزقكم وأياهم

Al-Ancam, verses 151-152

- And kill not your children because of poverty. We provide for you and for them.

The Cattle

In the following verse the provisions of the sons are given precedence over the provisions of the fathers where the Qur'an addresses the rich to the exclusion of the poor:

- ولا تقنلوا أولادكم خشية إملاق ـ نحن نرزقهم وأياكم

Al-Isra, verses, 31-32

- And kill not your children out of fear that your providing for them would impoverish you.

We provide for them and for you.

The Children of Israel 
We notice that all previous translations of the Qur'an have failed to capture this sense of the last verse simply because the translator did not heed the notional or thematic relations hysteron-proteron serves in the Qur'an.

\section{Conclusion}

Hysteron-proteron is a universally-used rhetorical device which creates a meetingground for stylistic, artistic, and thematic functions of narrative, poetic, and religious texts respectively. Its triune performance stems out mainly from its polyfunctional role as it relates to verbal expression by both its form and content. It also shares art in its power to affect linguistic highlighting or prominence in the text architecture and layout.

Moreover, hysteron-proteron registers a sort of departure from the norm. If this departure persists as to create, among other deviancies, a distinctive feature of a given writer, it turns into a stylistic personality indicator. Otherwise, when hysteronproteron is generically used for the same function in a special text such as poetic, narrative or religious text, it tends to function as a generic, not stylistic, indicator as in the model expounded in this paper.

However, the use of hysteron-proteron in any literary text is polyfunctional for, in addition to generic and text-type affinity in these texts as set off against technical and science texts, there exists a functional affinity, for every artistic effect harbours both stylistic and thematic overtones. Thus, poetry comprises style, art, and thought. And whereas style is subordinated in sacred literature to thought, poetic aesthetics is subordinated in narrative texts to style while thought is given an equivalent secondary position in both narrative and poetic texts.

Hysteron-proteron used in Modern Literary Arabic in general and narrative in particular is a mostly Western stylistic borrowing. This suggests that while structural aspect of Arabic poetry somehow persisted across ages, story-telling has recently witnessed a grand mutation. Religious texts on the other hand, present an archaeological museum of literature and they, therefore, serve a coefficient for comparison and evaluation rather than a developing source of information by themselves.

Finally, it goes without saying that by virtue of its strong affinity to syntax, style, and semantics, hysteron-proteron does involve translation problems which become all-too-salient when the languages concerned stand on two almost diametricallyopposing poles such as Arabic and English.

\section{NOTES}

1. The insertion of the negation particle not in different places within a sentence serves a stylistic markedness, and consequently influences the meaning of the sentence: e.g., I don't suppose the hypothesis is correct., I suppose the hypothesis isn't correct.

2. In poetry hysteron-proteron is termed anastrophe while on the level of single words, morphemes or certain adverbial replacements, it is termed metathesis, cleft sentence, extraposition, foregrounding, markedness, prominence, and salience respectively.

3. Desinential flection eر إب in Arabic is one of the basic pillars of classical Arabic grammar as far as functional delineation and distribution of different elements in the sentence are concerned. For instance, the sequences S-V-O and O-V-S do in English express two different statements and should, accordingly, be put in two different sentences while both these sequences expressing two different statements are, with the help of عراب put in only one Arabic sentence. Inflectionality and highly flexible word-order make many anastrophic English sentences in literary texts and ordinary discourse look normal in their Arabic translations: About the woodland I will go does not look as impressive in 
its Arabic version إلى الغابة سوف أذهب as it does in the English original by Housman, A.E. (1859-1936) in a beautiful poem entitled: Loveliest of Trees. It is noteworthy that Housman's style is replete with anastrophes.

4. English is considered rigid in this context in relation to Arabic. But it is actually less rigid in comparison to Hindi, Japanese, and Turkish whose word-order lies in the category (SOV) which is generally regarded as rigid per se.

5. E.E. Cummings introduced several innovations in theme, technique, and structure. His style in poetry recalls that of Dali's in painting.

6. It is well worth bearing in mind, in this connection, that hysteron-proteron can be motivated unconsciously as well. A given predicate can precede its subject when the subject does psychologically function as predicate and vice versa. This is due to the lack of correspondence between grammatical and psychological subject and predicate. Vygotsky distinguishes the psychological subject and predicate from the grammatical subject and predicate. For instance, in the sentence (the clock fell). The clock is the grammatical subject and fell is the grammatical predicate, while in psychology the act of falling of the thing that has fallen carries the logical stress and it as such becomes a psychological subject. So, in the above sentence, fell is the psychological subject and the clock is the psychological predicate. In fact, any element in a sentence can carry the logical stress and assume the place of a psychological subject. In hysteron-proteron, grammar tends to give credit to psychology and provides us with a frame of reference for interpreting language deviancies and unexpected turns of phrase. It seems that this case strongly applies to certain individuals such as Keats, Kafka, Coleridge, De Quincey, as well as most opium-eaters and romantics since to such mentalities it does not mean or change anything whether the cart goes before the horse of the horse goes before the cart.

7. Between, behind, above, under, below, and over are considered adverbs, not prepositions, in Arabic.

8. Nagib Mahfouz's style is distinguished by a highly descriptive technique employed to dramatize the social value system in Arab-Muslim society seen from an intimate personal experience. It is worth mentioning that Nagib Mahfouz had translated from English with the aim to improve his competence at English. It seems that his narrative style had been technically influenced by his earlier translating effort as well as by his interest in history. See Nagib Mahfouz: A Personal Interview. In: Fikrun wa Fann. ed. Rosemarie M. Holl, Internationes, No. 48-49, 1989, pp. 82-84.

9. Sound and Fury is a good example of his singular style.

10. See his The secret Room as an exponent of his style.

\section{REFERENCES}

Az-Zawzani (1971): A Commentary on the Seven Odes, Beiruth, Dar Sadir.

Bateson, V. C. (1970): Structural Continuity in Poetry, Paris and The Hague, Mouton.

Bronowski, J.(1980): The Ascent of Man, BBC Pubs, p. 115-116.

Carey, J. and A. Fowler (eds.) (1968): The Poems of John Milton: Book X, London, Longmans.

Crone, P. and M. Cook (1977): Hagarism: The Making of the Islamic World, New York and London, Cambridge University Press.

Johnson-Davies, D. (1981): Modern Arabic Short Stories: The Doum Tree of Wad Hamid (by TAYEB SAliH), London, Heinemann.

Hawkins, J. A. (1983): Word Order Universals, New York, Academic Press.

Jakobson, R. (1972): "Verbal Communication," Scientific American 227, p. 78-80.

Nicholson, R.A. (1979): A Literary History of the Arabs, London, Cambridge University Press.

Pickering, J. H. and J. D. Hoeper (1982): Literature, Macmillan.

Pickthall, M. M. (1981): The Holy Qur'an, Hyderabad, The Heights.

Richards, J. et al. (1989): Longman Dictionary of Applied Linguistics, Longman.

Scholes, R. (1985): Textual Power, London, Yale University Press.

Shakespeare, W. (1971): The Complete Plays, Oxford.

Shklovsky, V. (1989): “Art as technique," in Davis, R. C. and R. Schleifer, Contemporary Literary Criticism, Longman.

Speiti, M. (1986): A Commentary on Diwan al-Mutanabbi, Dar' Al-Kutub 'l-cilmiyya.

Stetкevych, J. (1970): The Modern Arabic Literary Language: Lexical and Stylistic Developments, The University of Chicago Press.

Wertsch, J. (1985): V. Vygotsky and the Social Formation of Mind, Harvard University Press. 